\title{
The subjective use of postural verbs in Afrikaans (II): a corpus analysis of $C P V$ en in Zefrikaans
}

\author{
Adri Breed \\ Subject group: Afrikaans and Dutch, Potchefstroom Campus, North-West-University, South Africa \\ E-mail: adri.breed@nwu.ac.za
}

\begin{abstract}
A general linguistic use of progressive aspect is to express some kind of subjective meaning. In other words, this aspectual construction is applied to postulate the speaker's attitude towards or emotional involvement with a particular situation. Although this practice occurs in all three Afrikaans progressive constructions, it is clear that the postural progressive in Afrikaans in particular became specialised with respect to subjective expression. The $C P V^{l}$ en construction is even used in contexts where its meaning cannot be interpreted as progressive (for example, stative or anterior situation types), and furthermore this construction collocates significantly strongly with negative communication verbs (verbs like skinder 'gossip', kla 'complain' and pla 'bother'. The subjective use of progressive constructions in Afrikaans has not received much attention to date. In two complementary articles (this article and The subjective use of postural verb in Afrikaans (I): evolution from progressive to modal) the development and use of the $C P V$ en as subjective or interpretative construction, are investigated. The purpose of this second article is to conduct a corpus investigation in a corpus that is appropriate for optimally examining the subjective use of the $C P V$ en construction potential, namely a recent Afrikaans corpus characterised by non-standard, informal, spoken or conversational language. The Watkykjy.co.za Corpus 1.0 (2015), as a corpus of "Zefrikaans" is examined for this purpose. Whereas the first article focused on the development of the postular construction to express subjective or modal meaning, the purpose of this article is to investigate the use of the subjective $C P V$ en. From a grammaticalisation perspective, it is indicated that the different frequency relations are a first strong indication that $C P V$ en has been further grammaticalised in Zefrikaans than in Standard Afrikaans, and that the modal and subjective use of the construction is therefore probably also applied more productively in Zefrikaans. Secondly, a collexeme analysis is done of the main verbs that collocate with $C P V$ en and it is found that the Zefrikaans construction, similar to the manner in which it is used in Standard Afrikaans, collocates significantly strongly with seven verb categories, namely with verbs i) social interaction; ii) creative activity; iii) perception; iv) cognitive activity; v) biology; vi) inactivity; and vii) negative communication. In the Zefrikaans collocation list, however, there are many words with a strong modal or interpretive undertone, that are non-standard or informal, or can even be regarded as vulgar, crude and inappropriate. The results of

\footnotetext{
${ }^{1}$ The term CPV refers to cardinal postural verbs "which (commonly) profiles the Agent as assuming one of the [three] cardinal postures when carrying out the activity" (Lemmens 2005: 1). In this article the four postural verbs sit 'sit', staan 'stand', lê 'lie' and loop 'walk' are regarded as CPVs. In most typological literature on postural verbs, loop 'walk' is not regarded as a postural verb, as it rather is a dynamic activity verb. However, as indicated by Breed (2012), loop in Afrikaans has the same semantic features, lexical form and grammatical function as the grammaticalised $C P V$ en progressive, and in this article it is therefore considered and discussed entirely as a cardinal postural construction.
} 
the corpus investigation confirmed that the $C P V$ en construction mainly occurs in non-standard, informal, spoken or "conversational" Afrikaans.

Keywords: cardinal postural verb, CPV, grammaticalisation, postural, progressive, modal use, subjective, Zefrikaans

\section{Introduction}

This $^{2}$ article is one of two complementary articles describing the development and use of the Afrikaans $C P V$ en construction to express subjective or interpretive meanings. In the first of the two articles, namely The subjective use of postural verb in Afrikaans (I): evolution from progressive to modal, it was indicated how the four Afrikaans cardinal postular verbs (sit 'sit', staan 'stand', lê 'lie' and loop 'walk') developed from a construction that expresses body posture or orientation of a human subject, to a non-progressive construction that exclusively expresses modal meaning. It was also indicated that this construction is apparently not commonly used in Standard Afrikaans, because it does not appear very frequently in the Taalkommissie corpus $^{3}$ (2011) (TK corpus). The few examples that occur in the TK corpus, are all examples of contexts of informal and spoken language, for example character dialogue in direct or indirect speech, internal focalisation of the narrator, and texts that are presented to the reader in a narrative style, for example, blogs or letters.

It was concluded that when a corpus investigation of this construction is undertaken, a corpus should be chosen in which the construction is used more productively; in other words, a recent Afrikaans corpus characterised by non-standard, informal, spoken or "conversational" language use. Therefore, the focus of this second article is on a corpus investigation in such a corpus that is appropriate for optimally investigating the subjective use of the $C P V$ en construction. Whereas the first article focused on the development of the postular construction to express subjective or modal meaning, the purpose of this second article is to investigate the use of the subjective $C P V$ en construction.

This article consists of three content sections. In the first section, Zefrikaans as a language variety of Afrikaans, as well as the WKJ corpus are briefly discussed. In the second section, it is explained why the grammaticalisation theory is an appropriate theoretical framework for describing the development and use of the $C P V$ en construction, and a brief description of this theory is presented. In the third and final section, the corpus investigation of $C P V$ en in the Watkykjy.co.za corpus $1.0^{4}$ is presented.

\footnotetext{
${ }^{2}$ I would like to thank Tiana Smith for her invaluable input regarding the translation and interpretation of the Zefrikaans sentence examples, and Lande Botha and Karien van den Berg who provided great help on the conceptualisation of the argument and the statistical interpretations.

3 Further on the "TK corpus". This Afrikaans corpus was compiled by the Taalkommissie van die SuidAfrikaanse Akademie vir Wetenskap and Kuns (Taalkommissie 2011). This stratified, synchronic corpus of written Standard Afrikaans consists of about 60 million Afrikaans words. It comprises a variety of written texts, namely prose texts (approximately 6 million words), academic texts (approximately 24 million words) and nonfiction, non-academic texts such as newspapers, magazines and books (approximately 27 million words).

${ }^{4}$ Further on, the Watkykjy.co.za corpus 1.0 will be referred to as the WKJ corpus, and the website www.watkykjy.co.za will be referred to as WKJ.
} 


\section{Corpus discussion}

Unfortunately, there are few Afrikaans corpora available that are characterised by the language properties in question. For instance, there is not a sufficient ${ }^{5}$ corpus available of spoken Afrikaans, and most other commonly available or accessible Afrikaans corpora (for example the NCHLT Afrikaans corpus 1.0 2013; the NWU/Maroela Media corpus 1.0 2015; the NWU/Lapa corpus 1.0 2015; the PUK/Protea Book House corpus 2.0 2015; and the RSG news corpus 2.0 2015) - like the Taalkommissie corpus (2011) - consist of written Standard Afrikaans texts.

However, the VivA corpus portal (2016) provides a corpus that may be classified "as a unique body of informal, conversation language", namely the WKJ corpus (2015). It is a corpus made up of a collection of web articles published on WKJ, and serves as an example of a specific register variety ${ }^{6}$ of Afrikaans, so-called Zefrikaans ${ }^{7}$. Although this corpus contains material that can be quite offensive to some users, because of the subject matter and language use (VivA 2016), this corpus is ideally suited for an analysis of the subjective use of the postular progressive construction, as will be shown in this article.

\subsection{WKJ as a Zefrikaans corpus}

\subsubsection{The term "Zef"}

The origin of the term "zef" is difficult to determine, but it is believed that the term is derived from the motor vehicle Ford Zephyr, which was popular in South Africa particularly in the early 1970s (Fourie 2010):

The Zephyr later became a favourite among owners who liked to soup-up their engines and add fat tyres with shiny rims. With these souped-up Zephyrs, men would dice and wheel spin down the streets late at night. People from that era say these were mostly rough guys - real zefs.

The content of the WKJ website is written exclusively in Zefrikaans and "pays homage to Afrikaans slang ${ }^{8}$ and zef" (Mhambi 2010). According Mhambi (2010), the Afrikaans term zef "roughly [translates] to what we in South Africa also refer to as 'common': clapped-out Ford Cortinas with fur on the dashboard, tight mom jeans pulled up too high, 'synth-heavy ringtone rave', mullets. Zef isn't a music style, and it's not limited to any one culture or location, obviously, but www.watkykjy.co.za celebrates it particularly well in Afrikaans."

\footnotetext{
5 The available spoken Afrikaans corpora, namely the Gesproke Korpus van Afrikaans (Ponelis 1976) and the Korpus van Gesproke Afrikaans uit die vroeë 2000's (Van Rooy 2003), respectively consist of about 565000 words and 72000 words, and are both too small, and include too few examples of $C P V$ en to allow an adequate analysis of this construction.

${ }^{6}$ A register variety can be defined as the language varieties in which people act out their special interest or activity within a group (Carstens 2011: 291).

${ }^{7}$ Zefrikaans is a combination of the words Afrikaans and Zef.

${ }^{8}$ Slang involves a collection of crude words and expressions that have deliberately been selected to express a kind of mutual cohesion or solidarity with a certain group, etc. (Carstens 2011: 292).
} 
The Afrikaans rapper Snotkop, a.k.a. Francois Henning, explains that the term does not only have negative connotations, and he also associates it with "blue eyeliner, bleached hair, sweat bands and cars with overly powerful sound systems" (Fourie 2010).

According to the chief editor of the Woordeboek van die Afrikaanse Taal, Dr Frikkie Lombard, zef describes "what was considered kitsch back in the day, and has been reborn to mean nouveau riche. Thus if something is zef, it means it's something which usually [was] considered to be common, but nowadays has credibility" (Fourie 2010).

Grobler (2012: 18) defines the "zef culture" as a "social phenomenon where a generation of Afrikaners - mostly in their 30s - have embarked on finding their own cultural identity by disowning the values associated with their parents' generation - staunch Calvinism, nationalism, a whitepicket-fence existence that rested on collective values and morals".

Zef is also strongly associated with the internationally famous South Afrikaans music duo Die Antwoord, consisting of members Ninja and ¥o-Landi Vi\$\$er, who released a controversial music video, entitled "Zefside" (2010) ${ }^{9}$. In an interview with Culhane (2009), Ninja explains that "Zef is our flavour, our style. It means fucking cool. But even more cool than fucking cool. No one can fuck with your shit. Zef's the ultimate style, basically". He further explains that their music is characterised by "our own personal flavour and just keep it real you know, and represent where we're coming from and how we speak. The next album we're working on is called Ten\$ion, and on this album we want to rap more like tour guides of South Africa, like maintain our SA style and flavour but still bring it for people in the overseas to understand... with like 95\% English and then just a bit of Afrikaans”, to which ¥o-Landi adds "Afrikaans for all the swearing bits". The excessive use of swearwords, expletives and offensive expressions is indeed a typical feature of Zefrikaans, as becomes clear in WKJ's glossary ('Zef slang').

\subsubsection{The WKJ website and corpus}

As mentioned above, the WKJ corpus is compiled of web articles that were published on the WKJ website. This popular site came into existence at the end of 1999 and offers its guests a wide variety of information, all written in Zefrikaans. For instance, on the site there are links to articles ("snotstories"), interviews ("interviews"), news ("nuus"), a gossip column ("warm brokkies"), online games ("spykertafel"), an online store ("Zefshop") and even a Zefrikaans glossary ("zef slang").

The contributions on WKJ are written by several authors, but texts are screened by the administrators of the site before being published. The site is updated daily with new material, and gets about 95000 unique visits per month that generate approximately 500000 views. Approximately $55 \%$ of the visitors are male, $45 \%$ are female, and $80 \%$ of the visitors are South African. Most of the site's visitors live in Gauteng (50.67\%) and the Western Cape (24.61\%). Approximately $27.5 \%$ of the visitors are $18^{10}-24$ years old, about $30 \%$ are $25-34$ years old and about $15.5 \%$ are $35-44$ years old. The rest of the regular audience are 45 or older (Griffin 2016).

\footnotetext{
${ }^{9}$ The official music video is available on YouTube, at https://www.youtube.com/watch?v=Q77YBmtd2Rw

${ }^{10} \mathrm{WKJ}$ content is not suitable for visitors under the age of 18.
} 
The WKJ corpus comprises 1043756 words and was compiled in 2015. It has been made available on VivA's (2015) corpus portal.

\section{Grammaticalisation theory as a theoretical point of departure}

When the development and use of a grammatical construction, such as a progressive or modal construction, is investigated, it makes sense to proceed from a grammaticalisation perspective, because the grammaticalisation theory precisely focuses on the evolution of a lexical construction (in this case the CPV, which expresses body posture or orientation) to a grammatical construction (in this case, then, the subjective use of $C P V$ en). The grammaticalisation theory has already been discussed in a number of publications (including Breed 2012, and Breed and Van Huyssteen 2014), and therefore only some relevant aspects for the description of the grammaticalised $C P V$ en will be highlighted in this article.

In summary, grammaticalisation can be described as the process by which a lexical construction gradually develops and becomes generalised over time, to the extent that it performs a grammatical function in certain constructions, apart from the lexical meaning that it sometimes still expresses in other contexts (see, for example, Heine and Reh 1984: 11-12; Croft 1990: 257; Bybee, Perkins and Pagliuca 1994: 4-5; Hopper and Traugott 2003:1). There are especially five central assumptions about grammaticalisation that can be highlighted with a view to a corpus investigation into the development of subjective $C P V$ en constructs.

The first assumption is that a construction evolves or develops along a universal route. A universal route can be seen as the development path that an evolving construction follows. Hopper and Traugott (2003: 6) explain that from a typological perspective it appears as if the same routes may be found in different languages, and Bybee et al. (1994: 15) ascribe this correspondence between universal routes in different languages to the existence of shared cognitive and communicative patterns in language:

The degree of cross-linguistic similarity that recent studies have uncovered suggests that forces in language are pushing toward the selection of particular source material and movement along particular paths propelled by certain common mechanisms of change ... We attribute the fact that certain grammaticalization paths are common in diverse genetic and areal groups to the existence of common cognitive and communicative patterns underlying the use of language.

The principle of unidirectionality is the second relevant assumption regarding grammaticalisation. Language changes that evolve according to a grammaticalisation route, ought to take place in a certain direction - from less grammatical (or lexical) to more grammatical (Campbell and Janda 2001: 101). Since grammaticalisation processes always follow certain grammaticalisation routes, certain steps or phases should always occur in a specific order (Bybee et al. 1994: 13). These routes, with phases that occur in a fixed order, can also be called a cline.

The term "cline" is a metaphor for the empirical observation that crosslinguistically forms tend to undergo the same kinds of changes or have similar sets of relationships, in similar orders. (Hopper and Traugott 2003: 6-7) 
The development route of CPVs, which is discussed extensively in the first of these two complementary articles, clearly involves these two assumptions of grammaticalisation. The different phases in the development of the CPV - each marked by different successive steps is an example of a universal route followed by CPVs in different languages (for example, Bulgarian, Danish, Norwegian, Mandan and Kabyle - see Kuteva 1999) to develop from a lexical cardinal postular verb that expresses the posture or orientation of a human subject, to a grammatical auxiliary verbal periphrase that expresses progressive meaning, and later also modal meaning.

In the third instance, it is assumed that the original meaning of the word influences the grammaticalisation route that is followed. Thus, the lexical meaning of a construction in a specific manner determines the route that this grammaticalisation process is going to follow, as well as the grammatical function that the construction will perform (Campbell and Janda 2001: 101). In the previous article, it was indicated that locative constructions are likely to develop into progressive constructions of which the development of the Afrikaans CPV en construction is a specific example.

Semantic fading of an evolving construction takes place during grammaticalisation. This is a fourth assumption regarding grammaticalisation and implies that a shift of meaning takes place (see Bybee et al. 1994: 6; Bybee and Pagliuca 1985: 60). The literal or lexical meaning of a content word restricts its use to contexts where it is lexically possible for it to appear (for example, in Phase I contexts where sit as a CPV would literally mean that the human subject is in a sitting posture, such as sentence (1)). However, a word that has a grammatical function, has more usage possibilities, since it is no longer bound to its literal, original and lexical meaning (for example, in Phase V contexts where staan no longer necessarily indicates that the subject is in a standing posture, such as sentence (2)).

TK Hysit by die tafel en lees koerant.

he sit at the table and read newspaper

'He is sitting at the table and reading the newspaper.'

(2) TK Vir wat staan en nooi jy nou die vroumens? Het ek nie genoeg

for what stand and invite you now the woman have I NEG enough

probleme nie?

problems NEG

'Now why did you have to go and invite that woman? Don't I have enough problems already?'

A construction can generalise to such an extent that its original lexical meaning becomes totally absent and that the construction then is lexically transparent (lexical transparency or opacity, as described by Rhee 2008: 10). The more grammaticalised the meaning of a construction, the less the correspondence between the grammatical use of the developing construction and the original lexical meaning. Lehmann (1995: 127) explains this phenomenon as follows:

For the sake of simplicity, I will assume that the semantic representation of a sign consists of a set of propositions taken from some semantic metalanguage commonly called semantic components or features, and that those propositions 
which are conjoined (rather than disjoined) contribute to semantic complexity or semanticity of the sign (details in Lehmann 1978). Desemanticization, or semantic depletion (Weinreich 1963: 180) or bleaching, is then the decrease in semanticity by the loss of such propositions.

This semantic generalisation or fading brings the fifth assumption of grammaticalisation into effect, namely that the usage frequency of the construction starts to increase. Since the grammaticalising construction loses its lexical meaning, and since the grammatical construction can be used in more contexts than in its lexical use, the frequency of the construction increases. A high frequency of a grammatical construction can therefore often be an indication of a high degree of grammaticalisation. However, this is not to say that a construction with a high frequency is necessarily a grammatical construction, as some lexical constructions can also have a high frequency.

\section{Corpus investigation}

In The subjective use of postural verb in Afrikaans (I): evolution from progressive to modal, it was mentioned that there are few examples of the subjective $C P V$ en construction in the TK corpus. Breed and Brisard (2015: 14) indicate that nearly 4500 examples of the CPV en progressive are found in the TK corpus, and that only 63 of these examples are regarded as $C P V$ en constructions with subjective uses (therefore only about $1.4 \%$ of the $C P V$ en constructions in the TK corpus are used to express subjective meaning). A simple way to determine whether the subjective use of the $C P V$ en construction occurs more frequently in the WKJ corpus than in the TK corpus, could of course be to count how many of the $288^{11}$ $C P V$ en constructions found in WKJ corpus can be regarded as subjective. Table 1 provides a summary of the frequencies of each of the subjective $C P V$ en constructions in the TK and WKJ corpora. This shows that $C P V$ en is indeed used more frequently (in $72.6 \%$ of cases) as a subjective construction in an informal, non-standard Afrikaans variety such as Zefrikaans.

Table 1: Subjective uses of $C P V$ en in the TK and WKJ corpora

\begin{tabular}{|l|r|r|r|r|}
\hline & \multicolumn{2}{|c|}{ TK corpus } & \multicolumn{2}{c|}{ WKJ corpus } \\
\hline & Total frequency & Subjective uses & Total frequency & Subjective uses \\
\hline sit en & 2301 & 25 & 159 & 112 \\
\hline staan en & 1492 & 36 & 90 & 69 \\
\hline lê en & 706 & 0 & 34 & 23 \\
\hline loop en & 220 & 2 & 5 & 5 \\
\hline Total & $4719(100 \%)$ & $63(1.4 \%)$ & $288(100 \%)$ & $209(72 \%)$ \\
\hline
\end{tabular}

A comparison and conclusion such as the one above is problematic, however, because there are a number of factors that should be taken into account when the subjective use of the CPV en is investigated. First, the subjective interpretation of a construction is extremely pragmatic, and the subjective interpretation can often only be inferred from the larger textual context in which the sentence is used. In example sentence (3), "koek ${ }^{12}$ bak" 'bake cake' will by no means not in itself be an expression of "the speaker's opinion, attitude or feelings towards a particular

\footnotetext{
${ }^{11}$ Frequencies of different progressive constructions are discussed in section 4.1.

12 "Koek" is an Afrikaans slang word with a profane reference to the vagina (Transwiki 2016). From the context, it can thus be concluded that the sentence refers to tanning naked in the sun.
} 
situation" (see Van Rooy 2006: 43). However, when the bigger context is considered (see sentence 4), as well as the semantic incompatibility of the CPV le 'lie' with the main verb phrase koek bak, it can be deduced that this sentence is highly grammaticalised, and therefore also needs further interpretation. The question then of course arises as to whether it is precisely this use of the $C P V$ en that expresses the subjective or interpretive meaning; or whether it is simply because of the context in which the construction is used.

\section{(3) WKJ Ons kan vir ure hier lê en koek bak!}

we can for hours here lie and cake bake

Lit.: 'We can be lying here for hours, baking cake.'

(4) WKJ Al wat ons doen is om al ons klere uit te trek, die strandhoedens langs all what we do be to all our clothes out INF.PRTCL pull the beach hats next to ons op te sit en ons rûe te le. Dan bak ons koek. Ons kan vir us on INF.PRTCL put and our backs INF.PRTCL lie then bake we cake we can for ure hier lê en koek bak! hours here lie and cake bake

'We just take off all our clothes, put on the beach hats next to us and lie on our backs. Then we lie naked in the sun. We can do this for hours.'

Secondly, it is possible that the subjective interpretation of a sentence can rather be attributed to the choice of the main verb that collocates with the $C P V$ en, as per se with the use of the $C P V$ en. In example sentence ((5)), the verb vreet 'feed' is used with sit en. Afrikaanse Skryfgoed 5 (2016) indicates various connotative associations of vreet, such as "ooreet [mense] 'overeating [people]', beesagtig eet 'eating like a beast', gulsig eet 'greedily eating', onmanierlik eet 'eating rudely', verorber 'consuming', verswelg 'engulfing', verslind 'devouring"'. Thus, it is evident that by simply electing to use vreet instead of the more neutral eet 'eat', results in a subjective interpretation.

(5) WKJ Jy sit en vreet tot 60 minute verby is, anders word jy gediskwalifiseer. you sit and feed until 60 minutes pass be otherwise become you disqualified 'You sit and stuff your face until the 60 minutes are up or you'll be disqualified.'

Thirdly, and related to the choice of the main verb, the subjective interpretation of a $C P V$ en sentence can in some sentences also be attributed to the choice of object with which collocation occurs. In sentence (6), kak 'shit' is used to indicate that it is not true that peace had been concluded. The fact that a swearword is used as an object here, in itself causes a subjective interpretation.

(6) WKJ So moenie dat iemand jou staan en kak vertel dat dit is waar die vrede so don't that someone you stand and shit tell that this be where the peace gesluit is nie.

closed be NEG

'So don't let someone tune you shit that this is where the peace treaty was signed.'

The use of modal particles or adverbs can fourthly impact the subjective interpretation of a sentence. Both sentences (7) and (8) can serve as examples. In sentence (7), taken from the TK corpus, the grammaticalised nou 'now' is used as a modal discourse marker, and in 
sentence (8) the swearword fokken 'fucking' is used as a modal adverb to give the sentence a subjective interpretation. If these two modal constructions were to be left out of the example sentences, the strong subjective interpretation of the sentences would probably be weakened or even totally lost.

(7) TK Nie dat 'n paar swaeltjies nou 'n somer staan en maak nie. NEG that a few swallows now a summer stand and make NEG

Lit.: 'Not that a pair of swallows make a summer.' ('One swallow does not a summer make.')

(8) WKJ Jy gaan vir jouself fokken sit en kyk.

you go for youreself fucking sit and watch

'You'll be fucking sitting there looking at yourself.'

Fifthly, the WKJ corpus is a corpus with an unusually big number of subjective sentences (whether they contain a CPV en or not), because the content on the website is characterised by tongue-in-cheek, cynical comments on various issues. The high frequency of subjective interpretations in Table 1 cannot necessarily be attributed to the specialised use of the $C P V$ en in the corpus, but perhaps rather to the style in which the WKJ content is written. In other words, many sentences (thus, not only sentences presented in the progressive) in the WKJ corpus are characterised by the contexts that are often expressed by $C P V$ en, such as sarcasm, cynicism, accusation, blame, hyperbole, etc.

Finally, as a result of the above effects on the high frequency of subjective $C P V$ en constructions, the interpretation and evaluation of a sentence mainly depends on speaker judgement. The frequencies shown in Table 1, could therefore probably differ depending on the person who assesses the example sentences as being subjective or not. Thus, to only count the subjective use of $C P V$ en in the WKJ corpus, would probably not be an accurate indication of the extent to which this construction is used as a subjective construction in this language variety.

In the first of these two articles, it was indicated that the subjective and modal use of the $C P V$ en construction is only found in the fourth and fifth stages of construction development; in other words, in the last two stages of the grammaticalisation route. It was also shown that these practices occur mainly in informal, non-standard and spoken or "conversational" Afrikaans. Since the subjective use of the construction is an indication of a high degree of grammaticalisation (in other words, a grammatical function that only occurs at a later stage of grammaticalisation), it can be deduced that - because its use becomes more productive in informal and nonstandard language - the $C P V$ en construction has become further grammaticalised in a variety like Zefrikaans than in Standard Afrikaans. It is assumed that Zefrikaans and Standard Afrikaans have a common ancestry, and therefore it is possible to make conclusions on the basis of comparison between these two varieties of Afrikaans about the extent to which they have become grammaticalised in terms of each other. In this next section, the $C P V$ en in Zefrikaans is analysed by comparing the results of a corpus investigation of this construction in the WKJ corpus with available results relating to the construction's use in the TK corpus, where relevant (see Breed 2012; Breed and Brisard 2015; Breed, Brisard and Verhoeven to appear). 


\subsection{Frequency}

As mentioned above, the frequency of a construction often correlates with the extent to which it has been grammaticalised. The different frequency relations of the three progressive constructions in the WKJ corpus are therefore relevant to assess to what extent the postular progressive construction has become grammaticalised in this informal, non-standard "conversational" corpus of Afrikaans. Because the frequency relations of the progressive construction in Standard Afrikaans have already been extensively described, it would also be useful to compare the applications of the constructions in the two varieties, in order to determine to what extent the progressive construction is used differently in this variety than in Standard Afrikaans. All frequencies of the TK corpus that are used for comparison in this section, have been taken from Breed et al. (to appear).

The first frequency relation to be considered is the general use of the progressive constructions in two varieties.

The TK corpus consists of 48498784 words, and a total of 17642 periphrastic progressive constructions have been found in the corpus. The WKJ corpus is considerably smaller than the TK corpus (with only 910911 words), and 702 periphrastic progressive constructions have been found in this corpus. Although the two corpora are not comparable in size, the relative frequency indicates that progressive constructions are used more in the WKJ corpus than in the TK corpus.

Table 2: Total frequencies of progressive constructions in the TK and WKJ corpora.

\begin{tabular}{|l|r|r|r|}
\hline Corpus & Total corpus size & Frequency of PROGs & $\begin{array}{r}\text { Relative frequency per } \\
100000 \text { words }\end{array}$ \\
\hline TK corpus & 48398784 words & 17642 results & 36.451 \\
\hline WKJ corpus & 910911 words & 702 results & 77.066 \\
\hline
\end{tabular}

The log-likelihood ${ }^{13}$ test (LL) was administered to establish statistical significance of the frequency differences, and the value of 303.66 was calculated. In order for the LL results to be statistically meaningful at the 95th percentile $(p<0.05)$, results need to be at least the critical value of 3.84. To be meaningful at the 99.99th percentile $(\mathrm{p}<0.0001)$, the critical value is 15.13 . Therefore, the LL result of 303.66 is highly significant at the 99.99th percentile $(\mathrm{p}<0.0001)$, because it is much higher than 15.13.

The fact that progressive constructions occur more significantly frequent in the WKJ corpus than the TK corpus, can be a possible first indication that the progressive has become further grammaticalised in Zefrikaans. It could therefore be expected that the more grammaticalised uses of the progressive (especially the subjective and modal postular construction) would occur more often in the WKJ corpus.

In an earlier section, it was noted that the Afrikaans $C P V$ en construction has become specialised to be the dedicated periphrastic progressive construction for use in subjective contexts. It is therefore to be expected that, if the $C P V$ en construction in this variety has been

\footnotetext{
${ }^{13}$ Results for the LL were calculated using the UCREL's online Log-likelihood and effect size calculator (see http://ucrel.lancs.ac.uk/llwizard.html).
} 
further grammaticalised than the standard variety, the relative frequency of this construction in the WKJ corpus will increase compared to the construction's relative frequency in the TK corpus.

Table 3 and Figure 1 offer a comparison of the proportions of the three different progressive constructions in the TK and WKJ corpora.

Table 3: Proportion of the progressive constructions in the TK and WKJ corpora

\begin{tabular}{|l|r|r|r|r|}
\hline & & TK corpus & \multicolumn{2}{|r|}{ WKJ corpus } \\
\hline Besig & 7992 & $(45 \%)$ & 275 & $(39 \%)$ \\
\hline aan die & 4929 & $(28 \%)$ & 128 & $(18 \%)$ \\
\hline CPV en & 4721 & $(27 \%)$ & 299 & $(43 \%)$ \\
\hline Total & 17642 & $(100 \%)$ & 702 & $(100 \%)$ \\
\hline
\end{tabular}

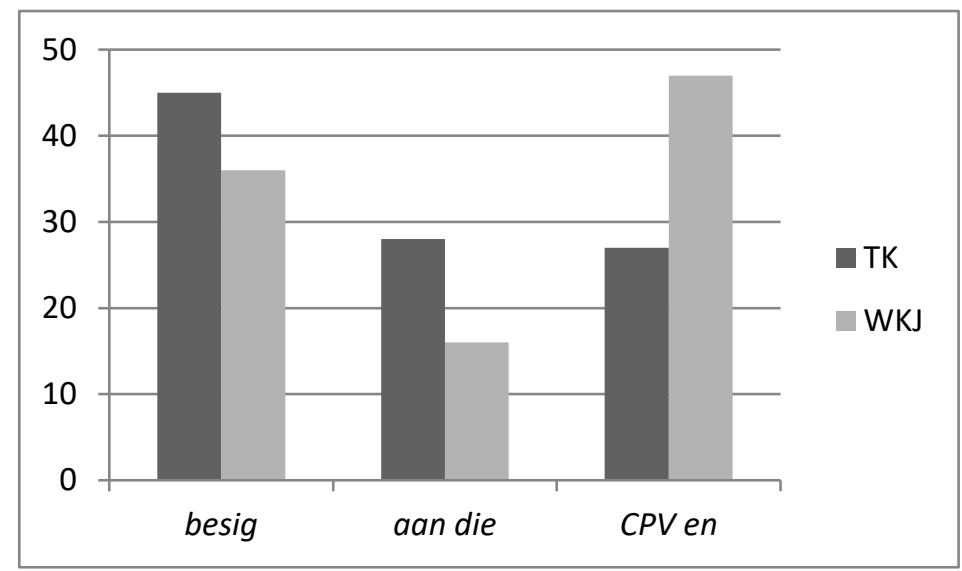

Figure 1: Proportions of progressive constructions in the TK and WKJ corpora

There is a difference between the proportions of the three progressive constructions in the two varieties. The besig construction is by far the most frequent progressive construction in the TK corpus, and $C P V$ en construction occurs least (with a relative frequency of $0.01 \%$ ). In contrast, the $C P V$ en construction is the most frequent progressive in the WKJ corpus (with a relative frequency of $0.03 \%$ ). There is thus a clear frequency increase of the $C P V$ en construction in the WKJ corpus. This significant difference in the frequency order is a second strong indication that the $C P V$ en construction has become further grammaticalised in informal non-standard Afrikaans than in Standard Afrikaans.

It is not only the difference between the relative frequencies of the $C P V$ en construction in the TK and WKJ corpora that is significant, but also the frequency differences between the three progressive constructions in the WKJ corpus. The relative frequency of the besig progressive is $0.02 \%$, and that of the $C P V$ en progressive is $0.03 \%$. This is indicative that the CPV en progressive is used significantly more in the WKJ corpus than the besig progressive. This is a third indication of a high degree of grammaticalisation of the $C P V$ en construction in informal non-standard Afrikaans.

A final proportion to be examined is the relationship between the lexical and grammatical use of each of the CPVs. As indicated in section 3, a construction that has become highly 
grammaticalised shows an increase in grammatical applications. If $C P V$ en in the WKJ corpus has therefore become further grammaticalised than in the TK corpus, there should be an increase in the relative frequency of grammatical applications in this corpus, compared to the TK corpus. Table 4 and Figure 2 show the differences between the two corpora that were investigated.

Table 4: Lexical vs. grammatical uses of the CPV in the TK and WKJ corpora

Proportions of postular verbs in the TK corpus

\begin{tabular}{|c|c|c|c|c|c|}
\hline $\mathrm{CPV}$ & Sit & Staan & Lê & Loop & Total \\
\hline Lexical CPVs & $\begin{array}{r}24408 \\
(91 \%)\end{array}$ & $\begin{array}{r}34679 \\
(96 \%)\end{array}$ & $\begin{array}{r}19971 \\
(97 \%)\end{array}$ & $\begin{array}{r}15014 \\
(99 \%)\end{array}$ & $\begin{array}{r}94072 \\
(95 \%)\end{array}$ \\
\hline Grammatical CPVs & $\begin{array}{r}2301 \\
(9 \%) \\
\end{array}$ & $\begin{array}{r}1492 \\
(4 \%) \\
\end{array}$ & $\begin{array}{r}706 \\
(3 \%) \\
\end{array}$ & $\begin{array}{r}220 \\
(1 \%) \\
\end{array}$ & $\begin{array}{r}4719 \\
(5 \%) \\
\end{array}$ \\
\hline Total & $\begin{array}{r}26709 \\
(100 \%) \\
\end{array}$ & $\begin{array}{r}36171 \\
(100 \%) \\
\end{array}$ & $\begin{array}{r}20677 \\
(100 \%) \\
\end{array}$ & $\begin{array}{r}15234 \\
(100 \%)\end{array}$ & $\begin{array}{r}98791 \\
(100 \%) \\
\end{array}$ \\
\hline \multicolumn{6}{|c|}{ Proportions of postular verbs in the WKJ corpus } \\
\hline $\mathrm{CPV}$ & Sit & Staan & Lê & Loop & Total \\
\hline Lexical CPVs & $\begin{array}{r}961 \\
(85 \%)\end{array}$ & $\begin{array}{r}490 \\
(84 \%)\end{array}$ & $\begin{array}{r}156 \\
(83 \%)\end{array}$ & $\begin{array}{r}453 \\
(99 \%)\end{array}$ & $\begin{array}{r}2060 \\
(88 \%)\end{array}$ \\
\hline Grammatical CPVs & $\begin{array}{r}159 \\
(15 \%) \\
\end{array}$ & $\begin{array}{r}90 \\
(6 \%) \\
\end{array}$ & $\begin{array}{r}45 \\
(7 \%) \\
\end{array}$ & $\begin{array}{r}5 \\
(1 \%) \\
\end{array}$ & $\begin{array}{r}299 \\
(12 \%) \\
\end{array}$ \\
\hline Total & $\begin{array}{r}1120 \\
(100 \%)\end{array}$ & $580(100 \%)$ & $189(100 \%)$ & $458(100 \%)$ & $\begin{array}{r}2347 \\
(100 \%) \\
\end{array}$ \\
\hline
\end{tabular}

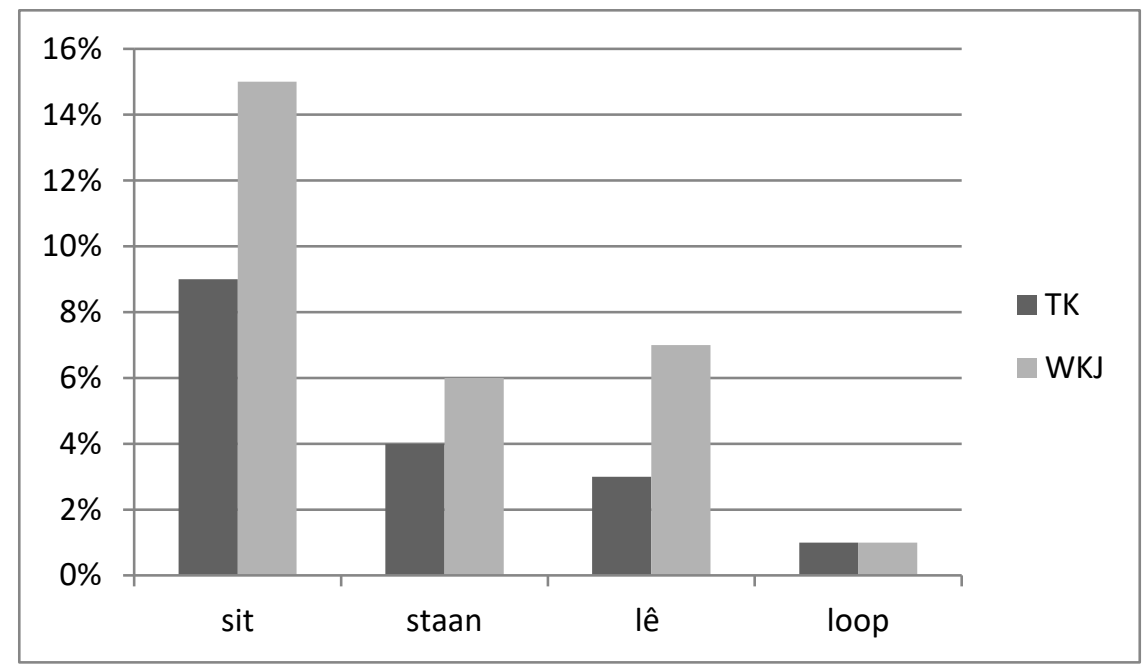

Figure 2: Lexical vs. grammatical uses of the CPV in the TK and WKJ corpora

Evidently, three of the four CPV constructions in the WKJ corpus are more frequently used as grammatical constructions than in the TK corpus. A total of $12 \%$ of the CPVs in the WKJ corpus are used in the grammatical CPV en construction, while it accounts for only $5 \%$ of the uses in the TK corpus. This finding is a fourth strong indication that the $C P V$ en construction in the WKJ corpus has indeed been further grammaticalised than in the TK corpus. 


\subsection{Collocations}

In this section, the verbs with which the postular construction in WKJ corpus collocates are investigated further. If a significant difference is found between the verbs with which the $C P V$ en in the WKJ corpus and TK corpus collocate, it may be an indication of semantic generalisation, because a grammatical construction that becomes further grammaticalised, will probably collocate with a wider range of verb types.

Breed et al. (to appear) conducted a collexeme analysis (see Stefanowitsch and Gries 2003; Gries and Stefanowitsch 2004a,b) of the verbs that collocate with the postular progressive in the TK corpus. They distinguish seven verb categories that are regularly used with $C P V$ en, namely verbs of i) social interaction (for example gesels 'converse', praat 'talk' and vertel 'tell'); ii) creative activity (for example $X_{N}$ doen ' $\mathrm{X}_{\mathrm{N}}$ do' and skryf 'write'); iii) perception (for example kyk 'look' and luister 'listen'); iv) cognitive activity (for example dink 'think' and lees 'read'); v) biology (for example slaap 'sleep', huil 'huil', eet 'eat' and drink 'drink'); vi) inactivity (for example wag 'wait' and toekyk 'look on'); and vii) negative communication (for example spog 'brag' and pronk 'boast'). It may be asked whether this classification also applies to the construction's use in the WKJ corpus. If it is indeed the case that $C P V$ en is used mainly in informal language as a subjective construction, it may for example be expected that the construction will also collocate further with verbs that call for modal, interpretative and subjective interpretation themselves. For this reason, a collexeme analysis ${ }^{14}$ is also made of the main verbs that collocate with $C P V$ en in the WKJ corpus.

Table 5 offers a list of the 30 strongest $^{15}$ verb collocations found in the WKJ corpus for the 4 postular words.

Table 5: Verb collocations of the CPV en construction in the WKJ corpus

\begin{tabular}{|c|c|c|c|c|c|c|c|c|c|c|c|}
\hline 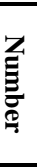 & 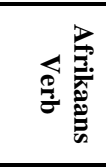 & 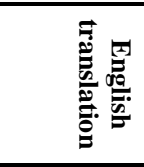 & 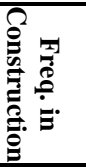 & 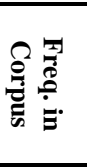 & 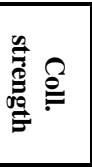 & 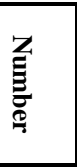 & 莡 & 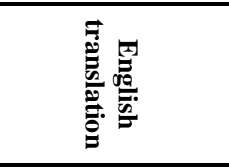 & 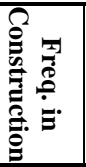 & 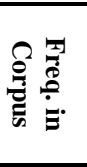 & 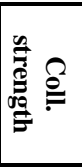 \\
\hline \multicolumn{12}{|c|}{ SIT EN } \\
\hline 1 & KYK & 'watch' & 23 & 1348 & 35.6 & 16 & $\begin{array}{l}\text { BROMMERS } \\
\text { HAP }\end{array}$ & $\begin{array}{l}\text { Lit: bite a blowfly } \\
\text { 'doing nothing' }\end{array}$ & 2 & 33 & 4.62 \\
\hline 2 & WAG & 'Wait' & 10 & 310 & 18.53 & 17 & OEFEN & 'practise' & 2 & 42 & 4.41 \\
\hline 3 & $\begin{array}{l}\text { (KAK) } \\
\text { PRAAT }\end{array}$ & 'Talk (shit)' & 9 & 501 & 14.44 & 18 & $\begin{array}{l}\text { BALLAS } \\
\text { BAK }\end{array}$ & $\begin{array}{l}\text { lit: bake balls } \\
\text { 'sunbathing naked' }\end{array}$ & 2 & 43 & 4.39 \\
\hline
\end{tabular}

${ }^{14}$ The collexeme analysis is a statistical method developed by Stefanowitsch and Grease (2003), and Gries and Stefanowitsch $(2004 a, b)$ to measure the association strength between a construction and lexical items with which it is associated. The method involves the Fisher exact test (cf. Pederson 1996) - a statistical significance test used in the analysis of contingency tables, and mainly used when sample sizes are small. Four different frequencies were measured in terms of one another, namely i) the frequency of the collexeme (L) in the construction (C); ii) the frequency of the collexeme (L) in all other constructions; iii) the frequency of the construction (C) with other lexemes than the collexeme (L); and iv) the frequency of all other constructions with other lexemes than the collexeme (L). The computer programme Coll.analysis 3.2a (developed by Gries 2014) was used to perform the collexeme analysis.

${ }^{15}$ Only verbs with a collocation strength above 1.30103 can be regarded as significant $(\mathrm{p}<0.05)$, and have been included in the list. Some verbs appear in the collocation list only once, and this raises the question whether valid conclusions can be drawn regarding the significance of the collocation strength of the relevant verbs. However, since the collocation strength was calculated by means of statistical tests, and since other words of the same type (for instance, verbs of biology) that appear in the list are also considered, these infrequent verbs are retained in the collocation list. 


\begin{tabular}{|c|c|c|c|c|c|c|c|c|c|c|c|}
\hline 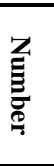 & 苞 & 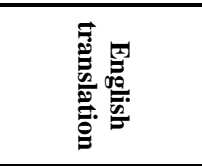 & 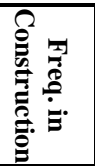 & 里 & 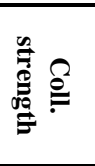 & 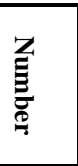 & 总 & 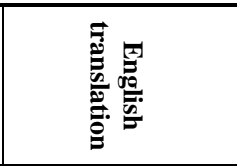 & 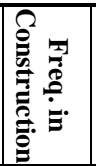 & 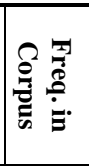 & 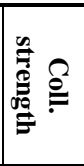 \\
\hline \multicolumn{12}{|c|}{ SIT EN } \\
\hline 4 & STAAR & 'Stare' & 4 & 35 & 9.97 & 19 & POEP & 'fart' & 2 & 71 & 3.95 \\
\hline 5 & DINK & 'Think' & 7 & 1014 & 8.48 & 20 & HEKEL & 'crochet' & 1 & 1 & 3.67 \\
\hline 6 & SUIP & $\begin{array}{l}\text { 'Drink like an } \\
\text { animal' }\end{array}$ & 4 & 93 & 8.23 & 21 & KREPEER & 'suffer' & 1 & 1 & 3.67 \\
\hline 7 & $\begin{array}{l}\text { VREET } \\
\end{array}$ & $\begin{array}{l}\text { 'Eat like an } \\
\text { animal' }\end{array}$ & 4 & 106 & 8 & 22 & NADINK & 'ponder' & 1 & 1 & 3.67 \\
\hline 8 & HUIL & 'Cry' & 4 & 125 & 7.71 & 23 & OMWENS & $\begin{array}{l}\text { 'wishing } \\
\text { something was } \\
\text { over' }\end{array}$ & 1 & 1 & 3.67 \\
\hline 9 & DOEN & 'Do' & 6 & 1232 & 6.46 & 24 & UITFORSEER & $\begin{array}{l}\text { lit: force out } \\
\text { 'defecate' }\end{array}$ & 1 & 1 & 3.67 \\
\hline 10 & LUISTER & 'Listen' & 4 & 282 & 6.3 & 25 & TOS & \begin{tabular}{|l|} 
'wank' / \\
'masturbation'
\end{tabular} & 2 & 129 & 3.43 \\
\hline 11 & DRINK & 'Drink' & 4 & 348 & 5.94 & 26 & AFTEL & 'count down' & 1 & 2 & 3.37 \\
\hline 12 & TUNE & 'Tell' & 5 & 917 & 5.71 & 27 & SKATERLAG & 'laugh out loud' & 1 & 2 & 3.37 \\
\hline 13 & GIGGEL & 'Giggle' & 2 & 13 & 5.45 & 28 & \begin{tabular}{|l} 
(DRATIES) \\
KAP
\end{tabular} & $\begin{array}{l}\text { Lit: chopping } \\
\text { wires } \\
\text { 'masturbation' }\end{array}$ & 2 & 150 & 3.3 \\
\hline 14 & \begin{tabular}{|l|} 
PIS \\
\end{tabular} & 'Piss' & 3 & 192 & 4.96 & 29 & AFLAG & 'laugh (it) off' & 1 & 3 & 3.19 \\
\hline 15 & $\begin{array}{l}\text { SKOON- } \\
\text { MAAK }\end{array}$ & 'Clean' & 2 & 19 & 5.11 & 30 & \begin{tabular}{|l} 
(VELLE) \\
KLAP
\end{tabular} & $\begin{array}{l}\text { LIT: clapping skin } \\
\text { 'masturbation' }\end{array}$ & 2 & 174 & 3.19 \\
\hline \multicolumn{12}{|c|}{ STAAN EN } \\
\hline 1 & WAG & 'wait' & 6 & 310 & 12.05 & 16 & MEDITEER & 'meditate' & 1 & 2 & 3.7 \\
\hline 2 & PIS & 'piss'/ 'urinate' & 5 & 192 & 10.77 & 17 & NIKSDOEN & $\begin{array}{l}\text { 'idle’' / ‘do } \\
\text { nothing' }\end{array}$ & 1 & 2 & 3.7 \\
\hline 3 & HUIL & 'cry' & 4 & 125 & 9.07 & 18 & $\begin{array}{l}\text { ROND- } \\
\text { SPRING }\end{array}$ & 'jump around' & 1 & 2 & 3.7 \\
\hline 4 & MAAK & 'make' & 7 & 2106 & 8.66 & 19 & TJANK & 'cry like a dog' & 1 & 3 & 3.53 \\
\hline 5 & GIL & 'scream' & 3 & 49 & 7.77 & 20 & \begin{tabular}{|l|} 
TOEKYK \\
\end{tabular} & 'look on' & 1 & 3 & 3.53 \\
\hline 6 & KYK & 'look' / 'watch' & 5 & 1348 & 6.55 & 21 & VERTEL & 'tell' & 2 & 286 & 3.41 \\
\hline 7 & BEDEL & 'beg' & 2 & 9 & 6.46 & 22 & JOL & $\begin{array}{l}\text { 'jam'/ 'playing } \\
\text { music' }\end{array}$ & 2 & 375 & 3.18 \\
\hline 8 & KERM & 'moan' / 'whine' & 2 & 22 & 5.65 & 23 & BROM & 'mumble' & 1 & 7 & 3.16 \\
\hline 9 & STAAR & 'stare' & 2 & 35 & 5.24 & 24 & BRUL & 'roar' & 1 & 9 & 3.05 \\
\hline 10 & SUIG & 'slurp'/ 'suck' & 2 & 60 & 4.77 & 25 & $\begin{array}{l}\text { (APIE) } \\
\text { WURG }\end{array}$ & $\begin{array}{l}\text { Lit: Wring monkey } \\
\text { 'masturbating' }\end{array}$ & 1 & 9 & 3.05 \\
\hline 11 & BOU & 'build' & 2 & 81 & 4.51 & 26 & BREI & 'knit' & 1 & 10 & 3.01 \\
\hline 12 & KIES & 'choose' & 2 & 127 & 4.12 & 27 & GRIN & 'grin' & 1 & 10 & 3.01 \\
\hline 13 & AFLUISTER & 'eavesdrop' & 1 & 1 & 4.01 & 28 & PIEPIE & 'wee' / 'wee-wee' & 1 & 10 & 3.01 \\
\hline 14 & OPGRAWE & $\begin{array}{l}\text { 'dig out' / } \\
\text { 'unearth' }\end{array}$ & 1 & 1 & 4.01 & 29 & HOLSWAAI & $\begin{array}{l}\text { LIT: Shake ass } \\
\text { 'dance' }\end{array}$ & 1 & 11 & 2.96 \\
\hline 15 & SERENADE & 'serenade' & 1 & 1 & 4.01 & 30 & OMDRAAI & 'turn around' & 1 & 12 & 2.93 \\
\hline \multicolumn{12}{|c|}{$L \hat{E} E N$} \\
\hline 1 & SLAAP & 'sleep' & 5 & 189 & 13.06 & 14 & SKATER & 'laugh out loud' & 1 & 6 & 3.66 \\
\hline 2 & \begin{tabular}{|l} 
SLINGER \\
\end{tabular} & 'stumble' & 2 & 17 & 6.76 & 15 & ONTSPAN & 'relax' & 1 & 9 & 3.49 \\
\hline 3 & \begin{tabular}{|l} 
TAN \\
\end{tabular} & 'tan' & 2 & 20 & 6.62 & 16 & REK & 'stretch' & 1 & 20 & 3.14 \\
\hline 4 & SPEEL & 'play' & 3 & 535 & 5.96 & 17 & KYK & 'look' / 'watch' & 2 & 1348 & 2.95 \\
\hline 5 & \begin{tabular}{|l|} 
PURRR \\
\end{tabular} & 'purr' & 1 & 1 & 4.44 & 18 & KRY & 'get' & 2 & 1406 & 2.91 \\
\hline 6 & UITBEWE & $\begin{array}{l}\text { Lit: shiver } \\
\text { 'having a } \\
\text { hangover' }\end{array}$ & 1 & 1 & 4.44 & 19 & POEP & 'fart' & $\begin{array}{c}1 \\
1\end{array}$ & 71 & 2.59 \\
\hline 7 & \begin{tabular}{|l} 
VIBREER \\
\end{tabular} & 'vibrate' & 1 & 2 & 4.14 & 20 & \begin{tabular}{|l|} 
FIGHT \\
\end{tabular} & 'fight' & 1 & 81 & 2.53 \\
\hline 8 & SPARTEL & 'struggle' & 1 & 3 & 3.96 & 21 & SUIP & $\begin{array}{l}\text { 'drink like an } \\
\text { animal' }\end{array}$ & 1 & 93 & 2.47 \\
\hline 9 & TAP & 'tap' & 1 & 11 & 3.4 & 22 & ROL & 'roll' & 1 & 140 & 2.3 \\
\hline 10 & SMELT & 'melt' & 1 & 13 & 3.33 & 23 & RUK & 'shake' & 1 & 176 & 2.2 \\
\hline 11 & TOEKYK & 'look on' & 1 & 3 & 3.96 & 24 & ROOK & 'smoke' & 1 & 185 & 2.18 \\
\hline 12 & $\mathrm{POO}$ & 'poo' & 1 & 5 & 3.74 & 25 & WAG & 'wait' & 1 & 310 & 1.95 \\
\hline 13 & PROBEER & 'try' & 2 & 572 & 3.69 & & & & & & \\
\hline \multicolumn{12}{|c|}{ LOOP EN } \\
\hline 1 & BRAG & 'brag' & 1 & 15 & 4.08 & 3 & PRAAT & 'talk' & 1 & 501 & 2.56 \\
\hline 2 & VERTEL & 'tell' & 1 & 286 & 2.8 & 4 & TUNE & 'tell' & 1 & 917 & 2.3 \\
\hline
\end{tabular}


Notably, the seven categories that are represented by Breed et al. (to appear), also appear in this WKJ collocation list. Even more noteworthy, however, is the fact that the specific words that appear in the TK collocation list differ much from those found in the WKJ collocation list. Besides the expected verb collocations, many of the words that appear in the collocation list are interpreted as verbs with a strong modal undertone, and some may even be considered as non-standard, slang or vulgar words.

In the verb category of social interaction, the expected verbs praat and vertel occur; whereas gesels and kuier, which are very strong collocations of $C P V$ en in Standard Afrikaans, are totally absent in the collocation list of the WKJ corpus. Furthermore, praat occurs only in one sentence (sentence 12) without vulgar nouns like tos 'nonsense' (example sentence 9) or kak 'shit' (sentence 10). Even the verb vertel is used in this manner (example sentence 11).

(9) WKJ Karakters sou nie sommer net sit en tos praat en tee suip nie. characters would ${ }_{\text {NEG }}$ just because sit and toss talk and tea suck/booze ${ }_{\text {NEG }}$ 'Characters wouldn't just sit around talking shit and guzzling tea.'

(10) WKJ Jy kan even betaal en gaan sit en luister hoe Gareth Cliff kak praat as jy you can even pay and go sit and listen how Gareth Cliff shit talk if you rêrig fokken kwaad is vir jouself. really fucking angry be for yourself 'You can even pay to go sit and listen to Gareth Cliff talking shit if you are really that fucking pissed off with yourself.'

(11) WKJ So moenie dat iemand jou staan en kak vertel dat dit is waar die vrede so don't that someone you stand and shit tell that this be where the peace gesluit is nie. closed be NEG

'So don't let someone tune you shit that this is where the peace treaty was signed.'

(12) WKJ 85 Jarige krimpie sit en praat met sy tottie.

85 year-old crimp sit and talk with his penis

'85 Year-old fart sits and talk to his willy.'

In the TK corpus staan en dans is a strong collocation in the category for creative activities (see Breed et al. to appear). In the WKJ corpus the verb dans 'dance' is not used as a strong collocation, but rather its vulgar synonym, holswaai 'shake ass' (see example sentence (13)).

(13) WKJ Jy staan en holswaai op iets belagliks soos Bon Jovi se "Living on a you stand and ass shake on something ridiculous like Bon Jovi's living on a Prayer". prayer

'You stand around shaking your ass (arse) to something ridiculous like Bon Jovi's "Living on a prayer".'

Just as in the TK corpus, the perception verbs kyk 'look' en luister 'listen' collocate significantly strongly with $C P V$ en in the WKJ corpus. However, verb with a strong modal interpretation, namely afluister 'eavesdropping', also occurs significantly frequent (see 14). 
(14) WKJ En dan het jy by die deur staan en afluister terwyl jy in jou neus gekrap and then have you at the door stand and eavesdrop while you in your nose picked en hardop gedink het: "Ek het altyd gedog baba's kom by mamma's se and loudly thought have I have always thought babies come at moms's boude uit..."

bums out

'And then you stood eavesdropping at the door while you picked your nose and thought out loud: 'I always thought babies came out of mommies' bums...'

It is especially the so-called biological verbs, however, that differ vastly from the TK collocation list. In the TK collocation list, for example, the verbs eet 'eat', drink 'drink' and huil 'cry' are indicated as typical verb collocations of $C P V$ en. Synonymous verbs found in the WKJ corpus collocation list are respectively vreet 'feed/eat like an animal' (see again example sentence 5), suip 'suck/drink like an animal' (example sentence 15) and tjank 'howl' (example sentence 16). There are also three other biological verb types that are found in the WKJ corpus, but not in the TK corpus, namely verbs that express that the subject is sweating (uitbewe, smelt and tap for example sentence 17), masturbating (draties klap, velle klap, apie wurg and tos - see sentence 18) or verbs expressing actions that are associated with defecation and urination (pis, poep, uitforseer, piepie and poo, as in example sentence 19).

(15) WKJ Jou baas sit in elk geval klaar en suip by die Dros. your boss sit in any way already and booze at the Dros 'Anyway, your boss is already busy getting pissed at Dros.'

(16) WKJ Daar aangekom is daar ' $n$ matroos wat sien sy staan en tjank en sy vertel hom there came at be there a sailor who see she stand and cry and she tell him van haar depressie.

of her depression

'When she got there, there was a sailor who saw her balling her eyes out and she told him about her depression.'

(17) WKJ Maaknie saak of jy Sondagaand soos ' $n$ nat, bang rot onder jou duvet make NEG matter if you Sunday evening like a wet scared rat under your duvet die naweek lê en uitbewe terwyl jy Carte Blanche kyk en of jy the weekend lie and out quiver while you Carte Blanche watch and if you mooi netjies getrou in jou flenniepajamapak gou jou werkklere beautiful neat diligent in your flannel pajama suit quickly your work clothes regsit voor jy agtuur begin snorkel nie. ready put before you eight-o'clock start snorkel NEG 'It doesn't matter if you are spending Sunday evening shivering out the weekend under your duvet while whatching Carte Blanche, or diligently getting your work clothes ready in your flannel pajamas before you start snoring at eight-o'clock.'

(18) WKJ Want die braaivleis smaak van 'n maand terug voel nou soos 'n vergete because the barbeque meat taste of a month ago feel now like a forgotten gedagte van sit en tos op ' $n$ warm klip toe ons nog ' $n$ kinders was, maar thought of sit and toss on a hot stone when we still a kids been but 
helaas, dit gaan teen slak pas.

unfortunately it go against snail pace

'Because the taste of last month's braai is now just a long lost memory like wanking on a warm rock when we were kids, but alas, it's continuing at a snail's pace.'

(19) WKJ Sy sal natuurlik met iets terugkap soos: "Maarliefie, doen wat ek she will of course with something back hit like but little love do what I doen en sit en pis".

do and sit and piss

'Obviously she will retaliate with something like: "But honey, do what I do and piss sitting down".'

The category for verbs expressing inactivity is also very productive in the WKJ corpus. Apart from the expected verb like wag 'wait', verbal expressions such as (niks/fokol/boggerol) doen, brommers hap, ballas bak, omwens and (dae) aftel, among others, also occur significantly frequently (see sentence 20). These verbs all have a strong negative modal interpretation in the specific contexts in which they are used, and they are primarily used to express irritation or boredom.

(20) WKJ At least kan jy vir so 22 minute sit en brommers hap by die werk, want at least can you for about 22 minutes sit and blowflies bite at the work because ons gooi jou weer onder die Pinocchio bus in.

we throw you again under the Pinocchio bus in

'At least you can sit around for 22 minutes at work without having to do anything, because we are again throwing you under the Pinocchio bus.'

Finally, given the already subjective nature of so-called negative communication verbs, it is not surprising that a number verb collocations can be shared in this verb category, for example (kak)praat, tune, giggel, aflag, gil, bedel, kerm-kerm, tjank, fight en brag (see sentence 21).

(21) WKJ Idols, of so iets waar deelnemers voor 'n klomp judges staan en Idols, or something alike where contestants before a bunch of judges stand and kerm-kerm tot die judges hulle óf beledig of sê hulle is die beste ding sedert tiete. whine until the judges them or insult or tell them be the best thing since tits 'Idols, or something like that where contestants stand whining in front of a bunch of judges until the judges either insult them or tell them they are the best thing since tits.'

The above confirms the findings in Breed et al. (to appear) that the CPV en significantly often combines with seven types of verbs. This feature apparently does not exclusively apply to the standard variety of Afrikaans, but the use of the construction in a standard variety differs from its application in a non-standard variety in terms of the specific verbs in the various categories that combine with the CPV. Earlier it was suggested that the subjective interpretation of the CPV construction can also be located in the "main verbs" with which it collocates. This observation is confirmed by the collexeme analysis. A considerable number of verbs that are included in the collexeme analysis, are clear examples of verbs or verbal constructions with a modal, inappropriate or interpretive meaning association. It is clear from this that the CPV en 
has become specialised as a subjective progressive, because it significantly strongly collocates with verbs with a modal undertone.

\section{Conclusion and summary}

This article is the second of a complementary pair of articles studying the development and use of the Afrikaans $C P V$ en construction to express subjective meaning. In the first article, titled The subjective use of postural verb in Afrikaans (I): evolution from progressive to modal, it was indicated that the Afrikaans construction developed in five phases from a cardinal postular verb that expresses the posture of a human subject, to a grammatical structure that expresses modal meanings. It was also stated that the subjective or modal use of the construction is mainly found in informal and non-standard varieties of Afrikaans. Therefore, in this second article, a corpus investigation was conducted to determine how the construction is used in a specific non-standard and informal variety of Afrikaans, namely Zefrikaans. Through comparing various frequency relations in the Zefrikaans corpus (the WKJ corpus) with those in a Standard Afrikaans corpus (the TK corpus), it was found that $C P V$ en has become more grammaticalised (thus, it displays more grammatical uses) in Zefrikaans than in Standard Afrikaans. This is a first possible indication that the subjective use of the $C P V$ en is indeed more productive in the informal non-standard variety of Afrikaans. The verbs with which $C P V$ en significantly strongly collocates, were also investigated. Through a collexeme analysis it was found that this construction - similar to the use of this construction in standard Afrikaans - significantly strongly collocates with seven verb categories, namely of verbs i) social interaction; ii) creative activity; iii) perception; iv) cognitive activity; v) biology; vi) inactivity; and vii) negative communication. It is noteworthy, however, that the specific words in these categories differ from the words in a Standard Afrikaans verb collocation list, because in the Zefrikaans verb collocation list there are many verbs that have a strong modal or interpretive undertone (for example, tjank instead of huil), verbs that are nonstandard or informal (for example, tune in instead of vertel), and verbs that may be regarded as vulgar, crude and inappropriate (for example pis and kakpraat). Hence, the verbs with which $C P V$ en collocates in the WKJ corpus, is a very strong indication that the grammatical construction is indeed used very productively as a modal or subjective construction in a non-standard and informal variety of Afrikaans, such as Zefrikaans.

\section{References}

Breed, A and G.B. Van Huyssteen. 2014. Aan die en besig in Afrikaanse progressiwiteitskonstruksies: die ontstaan en ontwikkeling (1). Tydskrif vir Geesteswetenskappe 54(4): 708-725.

Breed, C.A. 2012. Die grammatikalisering van aspek in Afrikaans: 'n semantiese studie van die perifrastiese progressiewe konstruksies. Potchefstroom: North-West University. [PhD].

Breed, C.A. and F. Brisard. 2015. Postulêre werkwoorde as progressiewe merkers in Afrikaans en Nederlands. Internationale Neerlandistiek. 53(1): 3-28.

Breed, C.A., F. Brisard and B. Verhoeven. To appear. Periphrastic progressive constructions in Afrikaans and Dutch: a contrastive analysis. Journal of Germanic Linguistics. [In press] 
Bybee, J.L. and W. Pagliuca. 1985. Cross-linguistic comparison and the development of grammatical meaning. In J. Fisiak (Ed.) Historical semantics, historical word formation. The Hague: Mouton de Gruyter. pp. 59-83.

Bybee, J.L., R.D. Perkins and W. Pagliuca. 1994. The evolution of grammar: tense, aspect and modality in the languages of the world. Chicago: University of Chicago Press.

Campbell, L. and R. Janda. 2001. Introduction: conceptions of grammaticalization and their problems. Language sciences, 23(2-3): 93-112.

Carstens, W.A.M. 2011. Norme vir Afrikaans. Pretoria: Van Schaik.

Croft, W. 1990. Typology and universals. Cambridge: Cambridge University Press.

Culhane, D. 2009. Die Antwoord: Zef so fresh. Vice Magazine, September. Available online: https://web.archive.org/web/20110813131343/http://www.viceland.com/int/v16n9/htdocs/dieantwoord-154.php (Accessed 1 September 2016).

Departement Kuns en Kultuur and CTexT. 2013. Afrikaans NCHLT Text Corpora. Potchefstroom: CTexT, North-West University.

Die Antwoord. 2010. Zef Side (Official). YouTube. Available online: https://www.youtube.com/watch?v=Q77YBmtd2Rw (Accessed 5 September 2016).

Fourie, M. 2010. “The Dummies guide to Zef”. News24, 16 February. Available online: http://www.news24.com/Entertainment/SouthAfrica/The-Dummies-guide-to-Zef-20100216 (Accessed 1 September 2016).

Gries, S. Th. 2014. Coll.analysis 3.5. A script for R to compute perform collostructional analyses.

Gries, S. Th. and A. Stefanowitsch. 2004a. Extending collostructional analysis A corpusbased perspective on 'alternations'. International Journal of Corpus Linguistics 9(1): 97-129.

Gries, S. Th. and A. Stefanowitsch. 2004b. Covarying Collexemes in the Into-causative. In M. Achard and S. Kemmer (Eds.) Language, Culture, and Mind. Stanford: CSLI Publications. pp. 225-236.

Griffin. 2016. RE:WKJ-inligting [e-mail correspondence]. 11-23 Aug.

Grobler, R. 2012. You lookin' at me? Die Media, 25 June. Available online: http://themediaonline.co.za/2012/06/you-lookin-at-me/ (Accessed 1 September 2016).

Heine, B. and M. Reh. 1984. Grammaticalization and reanalysis in African languages. Hamburg: Helmut Buske Verlag.

Hopper, P.J. and E.C. Traugott. 2003. Grammaticalization. 2nd ed. Cambridge: Cambridge University Press. 
Kuteva, T.A. 1999. On 'sit'/'stand'/“lie' auxiliation. Linguistics 37(2): 191-213.

Lapa-uitgewers and CTexT. 2015. NWU/Lapa-korpus 1.0. Potchefstroom: CTexT, NoordwesUniversiteit.

Lehmann, C. 1995. Thoughts on grammaticalization. 2nd ed. Erfurd: Arbeitspapiere des Seminars für Sprachwissenschaft der Universität Erfurt.

Lemmens, M. 2005. Aspectual posture verb constructions in Dutch. Journal of Germanic Linguistics 17(3): 183-217.

Maroela Media and CTexT. 2015. NWU-Maroela Media-korpus 1.0. Potchefstroom: CTexT, North-West University.

Mhambi, K. 2010. What is zef? Kameraad Mhambi, 2 February. Available online: http://mhambi.com/2010/02/what-is-zef/ (Accessed 1 September 2016).

Pedersen, T. 1996. Fishing for exactness. Proceedings of the SouthCentral SAS Users Group Conference (SCSUG) 96 in Austin, TX, 27-29 October. Available online: http://www.d.umn.edu/ tpederse/Pubs/scsug96.pdf (Accessed 13 July 2015).

Ponelis, F. 1976. Ponelis Gesproke Korpus van Afrikaans. Stellenbosch: Universiteit van Stellenbosch.

Protea Boekhuis and CTexT. 2015. PUK/Protea Boekhuis-korpus 2.0. Potchefstroom: CTexT, Noordwes-Universiteit.

Radio Sonder Grense and CTexT. 2015. RSG Afrikaanse korpus 2.0. Potchefstroom: CTexT, Noordwes-Universiteit.

Rhee, S. 2008. Cognitive semantic representation of instrumentals: crosslinguistic and grammaticalization perspectives. Studies in modern grammar 54: 123-146.

Stefanowitsch, A. and S. Th. Gries, S. 2003. Collostructions: Investigating the interaction of words and constructions. International Journal of Corpus Linguistics 8(2): 209-243.

Taalkommissie van die Suid-Afrikaanse Akademie vir Wetenskap en Kuns. 2011. Taalkommissiekorpus 1.1. Potchefstroom: CTexT, Noordwes-Universiteit.

Transwiki, 2016. Koek. Available online: http://end.translatum.gr/wiki/Transwiki:Koek (Accessed 8 September 2016).

Van Rooy, B. 2003. Korpus van Gesproke Afrikaans uit die vroeë 2000's. Potchefstroom: Noordwes-Universiteit.

Van Rooy, B. 2006. The extension of the progressive aspect in Black South African English. World Englishes 25(1): 37-64. 
Virtuele Instituut vir Afrikaans (VivA). 2016. Afrikaanse Skryfgoed 5. Available online: http://viva-afrikaans.org/index.php. (Accessed 10 September 2016).

Virtuele Instituut vir Afrikaans (VivA). 2016. Korpusportaal. Available online: http://korpus.viva-afrikaans.org/page/search (Accessed 8 September 2016).

WatKykJy. 2015. Watkykjy.co.za-korpus 1.0. Available online: http://korpus.vivaafrikaans.org/page/explore?lang=nl. (Accessed 8 September 2016).

Weinreich, U. 1963. On the semantic structure of language. In J.H. Greenberg (Ed.) Universals of language. Cambridge: MIT Press. pp. 142-216. 